\title{
TEMPOROMANDİBULAR EKLEM DİSFONKSİYONLU BİREYLERDE KONDİLE AİT KEMİK DEĞİŞİKLİKLERİNİN DENTAL VOLUMETRİK TOMOGRAFİ İLE DEĞERLENDİRİLMESİ ${ }^{\neq}$
}

EVALUATION OF CONDYLE BONE CHANGES BY DENTAL VOLUMETRIC TOMOGRAPHY
IN INDIVIDUALS WITH TEMPOROMANDIBULAR JOINT DYSFUNCTION ${ }^{\neq}$

\author{
Dr. Öğr. Üyesi Doğan DURNA*
}

Prof. Dr. A. Berhan YILMAZ*

Makale Kodu/Article code: 4352

Makale Gönderilme tarihi: 18.03 .2020

Kabul Tarihi: 25.06.2020

DOI : $10.17567 /$ ataunidfd. 757797

Doğan Durna: ORCID ID: 0000-0001-5341-6024

A. Berhan Yılmaz: ORCID ID: 0000-0001-5494-0290

öz

Amaç: Diş hekimliği radyolojisinde kullanılan cone-beam computed tomography (CBCT) veya dental volumetrik tomografi (DVT) sistemleri ile maksillofasiyal bölgenin sert dokularının her üç düzlemde de incelenmesi mümkün hâle gelmiştir. TME disfonksiyon şikâyeti olan genç ve erişkin bireylerdeki kondile ait kemik değişikliklerinin DVT ile semptomatik ve etiyolojik yönden incelemek, bu çalışmanın amacıdır.

Materyal ve Metod: Çalışmada, TME disfonksiyonlu 50 hastanın 100 eklemindeki sert dokular ve kondile ait kemik değişiklikleri yaş, cinsiyet ve parafonksiyonel aktivite gibi etiyolojik; ağrı, ses ve hareket değişikliği gibi semptomatik bulguları dental volumetrik tomografi ile incelendi. CBCT görüntülerinde 62 kondilde herhangi bir kemik değişikliği mevcut değilken; 38 kondilde kemik değişikliği tespit edildi. İnceleme neticesi 14 kondilde düzleşme, 19 kondilde osteofit ve 5 kondilde ise erozyon formasyonu görünümündeydi.

Sonuç: Araştırma sonuçlarına göre kondiler kemik değişikliği ile cinsiyet, ses ve hareket değişikliği arasında istatistiksel olarak anlamlı bir ilişki bulunmamışken; ağrı, yaş ve parafonksiyonel aktivitenin (diş sıkma ve gıcırdatma) varlığı açısından anlamlı ilişki tespit edilmiştir.

Anahtar kelimeler: Dental volümetrik tomografi, Disfonksiyon, Temporomandibular Eklem, Kondiler kemik.

\section{ABSTRACT}

Aim: With cone-beam computed tomography (CBCT) or dental volumetric tomography (DVT) systems used in dental radiology, it has become possible to examine the hard tissues of maxillofacial region in all three planes. The aim of this study is to investigate the symptomatic and etiological aspects of condyle bone changes in young and adult individuals with TMJ dysfunction with DVT.

Material and Method: Hard tissue and condyle changes in 100 joints of 50 patients with TMJ dysfunction were evaluated as etiological factors such as age, sex and parafunctional activity. Symptomatic findings such as pain, voice and movement changes were examined by dental volumetric tomography. CBCT images showed no bone changes in 62 condyles; Bone changes were detected in 38 condyles. As a result of the examination, flattening was observed in 14 condyles, osteophyte in 19 condyles and erosion formation in 5 condyles.

Conclusion: According to the results of the study, no statistically significant relationship was found between condylar bone change and sex, voice and movement changes; pain, age and presence of parafunctional activity (squeezing and grinding). Key words: Dental volumetric tomography, Dysfunction, Temporomandibular Joint, Condylar bone

${ }^{*}$ Atatürk Üniversitesi Diş Hekimliği Fakültesi, Ağız, Diş ve Çene Radyolojisi AD, Erzurum

F Tezimden üretilmiş bir yayındır.

Kaynakça Bilgisi: Durna D, Yllmaz AB. Temporomandibular Eklem Disfonksiyonlu Bireylerde Kondile Ait Kemik Değişikliklerinin Dental Volumetrik Tomografi İle Değerlendirilmesi. Atatürk Üniv Diş Hek Fak Derg 2020; 30: 351-9

Citation Information: Durna D, Yilmaz AB. Evaluation of Condyle Bone Changes by Dental Volumetric Tomography in Individuals with Temporomandibular Joint Citation Information: Durna D, Yilmaz AB. Evaluation
Dysfunction. J Dent Fac Atatürk Uni 2020; 30: 351-9

\section{GIRIS}

Temporomandibular eklem (TME); eklem bağları, kaslar, dil, dişler, yutak, yumuşak damak, duyu ve hareketle ilgili çevre sinirler ile baş ve boyundaki diğer tüm sistemler ve hatta ruhsal yapının uyumlu çalışması ile görevlerini gerçekleştiren insan vücudundaki en önemli ve karmaşık eklemlerdendir. ${ }^{1,2}$
TME disfonksiyonu toplumda sık görülen bir rahatsızlıktır ve hastalarda, kondile ait dejeneratif değişiklikler oldukça sık görülür. Temporomandibular eklem disfonksiyonu (TMED), artiküler disk ile artiküler eminens, fossa mandibularis ve mandibular kondil arasındaki normal dışı ilişkiyi tanımlayan, eklem ağrısı, eklem sesleri, çene hareketlerinde sınırlanma, kas 
ağrısı ve baş ağrısı ile karakterize durumlardır. TME kondil başında meydana gelen dejeneratif değişimlerde eklem bütünlüğü bozulduğu için bu durum, eklem disfonksiyonları içerisine dâhil edilmektedir. ${ }^{1,2}$

TME disfonksiyonunun teşhisi, klinik muayene ve değişik görüntüleme metotlarının birlikte kullanımıyla yapılabilmektedir. Bu disfonksiyonun değişik alt gruplar içermesi, bunların her birinin farklı tedavi uygulamalarını gerektirmesi ve farklı durumlarla kolaylıkla karıştırılabilmesi, teşhisini zorlaştırmaktadır. Bu amaçla diş hekimliği bünyesinde uzun yıllardır kullanılan panoramik radyografi ile lateral transkranio-oblik radyografi, TME'yi görüntülemede kolay ve maliyeti düşük görüntüleme yöntemleri olmasına rağmen eklemin iç yapısı hakkında fikir vermezler. Manyetik Rezonans Görüntüleme (MRG) eklem disfonksiyonlarının en önemli komponenti olan disk bozukluklarının teşhisinde en sık başvurulan yöntemdir. ${ }^{2}$ Girişimsel bir teknik olmayışı, sert ve yumuşak dokulara ait bulguların incelenebilmesi ve iyonize radyasyon taşımaması bu yöntemin avantajları arasında yer alır. Bilgisayarlı tomografi (BT) ise ekleme ait kemik yapılarının görüntülerini verdiği için özellikle ekleme ait dejeneratif kemik değişikliklerinin incelenmesinde yararlı bir görüntüleme yöntemi olarak kabul edilmektedir. ${ }^{2}$

Günümüzde diş hekimliği radyolojisinde kullanımı yaygınlaşan cone-beam computed tomography (CBCT) veya dental volumetrik tomografi (DVT) sistemleri, maksillofasiyal bölgenin sert dokularının görüntülenmesi için tasarlanmıştır. Bu sistem sayesinde geleneksel BT'lerde olduğu gibi her üç düzlemde de inceleme yapmak ve 3 boyutlu görüntü elde etmek mümkündür. Bu çalışmanın amacı, TME disfonksiyon şikâyeti olan genç ve erişkin bireylerdeki kondiler kemik değişikliklerinin, DVT inceleme yöntemi ile tanısal değerinin sonuçlarının paylaşılmasıdır.

\section{GEREÇ VE YÖNTEM}

Çalışmada Atatürk Üniversitesi Diş Hekimliği Fakültesi Ağız, Diş ve Çene Radyolojisi Ana Bilim Dalına TME'ye yönelik şikâyetlerle başvuran bireyler değerlendirmeye alınmıştır. TME'ye yönelik şikâyet olarak ağız açmada kısıtıılık, deviasyon ve defleksiyonun varlığı, klik, krepitasyon ve poping gibi eklem sesleri, kapalı ya da açık kilitlenme baş, yüz, kulak ağrısı gibi semptomlar aranmıştır. Bu semptomların görüldüğü hastalara TME disfonksiyonu ön tanısı konulmuştur. Klinik muayenesinde bu disfonksiyonu tarifleyen 25 kadın, 25 erkek toplam 50 hasta çalışmaya dâhil edilmiştir. Hastaların yaş ortalaması 34 olup, en genç hasta 18, en yaşlı hasta ise 60 yaşındadır.

Çalışma kapsamına alınan bütün hastalar, çalışmaya dâhil edilmeden önce yapılacak çalışma hakkında bilgilendirilmiş ve hastaların çalışmaya gönüllü olarak katılmak istediklerini belirten "Aydınlatılmış Onam Formu" imzalatılarak hastalardan izin alınmıştır.

Öncelikle kişisel bilgileri (adı, soyadı, cinsiyeti, doğum tarihi, doğum yeri, yaşı, mesleği, telefon numarası ve adresi) ve medikal anamnezleri kaydedilen bireylerin rutin ağız içi muayeneleri yapılmış, bu muayenede dişlerin mevcut durumu, diş eksiklikleri, mevcut protezlerin varlığı ve oklüzyon durumu değerlendirilmiştir. Yumuşak dokular ve periodontal yapılar değerlendirildikten sonra yüzde asimetri, yapısal çene anomalisi ve postür bozukluklarının varlığı kaydedilmiştir. Hastanın şikâyeti ve bu şikâyetlerin ne kadar süredir var olduğu belirlenmiş, daha sonra yapılan eklem muayenesinde eklem ve ilgili kas bölgesinde dinlenme ve fonksiyon sırasında palpasyona yönelik ağrıların varlığı araştırılmıştır. Son olarak hastada mevcut olabilecek parafonksiyonel alışkanlıkların varlığı incelenmiş ve tüm bunlar bir anamnez formuna kaydedilmiştir. Klinik muayenelerin tamamı tek bir kişi tarafından ve bilateral olarak yapılmıştır.

Klinik muayenesinde TME disfonksiyonu olan hastaların TME Dental Volumetrik Tomografileri, Atatürk Üniversitesi Diş Hekimliği Fakültesi, Ağız, Diş ve Çene Radyoloji Ana Bilim Dalında bulunan "Flat Panel Based Cone Beam Volumetric Computed Tomography" cihazıyla (NewTom FP, Quantitative Radiology, Verona, Italy) alınmıştır.

Çalışmada, her bir hastanın radyografi işlemlerinde standardizasyonun sağlanması için üretici firmaların belirttiği özelliklere tam olarak uyulmuştur. Cihazın gantri açısı sabit ve yere diktir. Cihaz, standart olarak $110 \mathrm{kVp}$ ve maksimum 15 mA'da konik ışın hüzme tekniği ile çalışmaktadır. Tarama başlangıcında alınan rehber imajların elde edilmesi sırasında hasta kafasının anatomik yoğunluğuna göre otomatik olarak doz seçimini sağlayan bir sisteme (AEC, automatic exposure control system) sahiptir. Tüp-flat panel dedektör sistemi, hasta başı etrafında $360^{\circ}$ lik tek bir rotasyon ile dönerken $13 \mathrm{~cm}$ yüksekliğinde ve $17 \mathrm{~cm}$ çapındaki silindirik bir alanda, her bir derecesinden bir görüntü elde etmek suretiyle toplam 360 adet hacimsel görüntü kazanacak şekilde çalışmaktadır. Cihazın gantri açısı sabit ve yere dik olduğundan, aksiyal planda TME- DVT incelemesi yapılmıştır. Aksiyal plan TME DVT inceleme, oksipitomeatal hatta veya sert damağa paralel alındı. Hasta masaya sırt üstü yatırılıp; 
baş, supin pozisyonda, ağız kapalı olacak şekilde masa üzerinde bulunan yastığa oksipital bölge üzerinden pozisyonlandırılarak tarama bitene kadar yeri hiç değiştirilmemiştir. Aynı işlem ağız açık pozisyonda tekrar edilmiştir.

DVT'de kondile ait kemik değişiklikleri incelenirken kemik değişikliğinin olmadığı ve açık kortikal kemik yüzeyinin olduğu durumlar normal, konveks formdan sapmış düz kemik kontürünün olduğu durum düzleşme (flattening), komşu subkortikal kemik ve kondil yüzeyindeki azalmış dansiteye sahip lokalize bir sahanın olduğu durumda erozyon ve yapının süperior ya da anterior yüzeyi üzerindeki marjinal bir kemik büyümesinin olduğu durumlar osteofitformasyonu olarak kabul edilmiştir.

Temporomandibular eklemde oluşan bu kemik değişiklikleri yaş, cinsiyet ve parafonksiyonel aktivite gibi etiyolojik; ağrı, ses ve hareket değişikliği gibi semptomatik bulguların varlığı aşağıda açıklandığı şekilde değerlendirilmiştir;

1. Yaş: Bireyler $18-39$ ve $40-60$ aralıklarında olmak üzere iki gurupta incelenmiştir.

2. Cinsiyet: Kız-Erkek

3.Parafonksiyonel aktivite: Hastaya sorulan "Geceleri veya gün içinde diş sıkma veya diş gıcırdatma gibi aktiviteler yapıyor musun?" veya "Çevrenizden herhangi biri sana dişlerini sıktığını veya gıcırdattığını söylüyor mu?" sorularına verilen cevabın karşılığ aranmıştır. Hastalarda dental atrizyonların varlığı diş sıkma veya gıcırdatmanın güvenilir bir işareti olmadığı için dikkate alınmamıştır.

4. Ağrı: Eklem ağrısı. Ağız açıkken eklemin lateral duvarına ve kapalıyken eklemin posteror duvarına yapılan standart palpasyonda her iki tarafta ortaya çıkan hassasiyet. Palpasyonda standart basınç uygulanmış ve ortalama 2 saniye sürdürülmüştür. Oluşan hassasiyet hastanın kendi ifadesine bağlı olarak negatif ya da pozitif olarak kabul edilmiştir.

5. Ses: Klik ve krepitasyon. Ağza açıp kapama hareketleri yaptırılarak bir steteskop (Littmann Classic II S.E. Stethoscope, St. Paul, U.S.A) varlığıyla her iki TME bölgesindeki eklem seslerinin varlığı belirlenmiştir.

6 . Elde edilen verilerin değerlendirilmesi yapılırken yukarda belirtilen kriterlere göre TME'ye ait kondiler kemik değişiklileri; yok (0) ve var (1) olarak kodlanmıştır. Veriler istatiksel "ki-kare" bağımsızlık testi ile değerlendirilmiş, "P" değerinin 0,05'ten küçük olması istatiksel olarak anlamlı kabul edilmiştir.

\section{BULGULAR}

TME disfonksiyonuna ait şikâyeti olan ve aynı şikâyetlerle Atatürk Üniversitesi Diş Hekimliği Fakültesi Ağız, Diş ve Çene Radyolojisi Ana Bilim Dalına başvuran bireyler değerlendirmeye alındı. Klinik muayenede TME disfonksiyon ön tanısı konulan bireylere öncelikle çalışma ile ilgili bilgi verilip etik kurul formu imzalatıldı (Ek 1). Temporomandibular eklem disfonksiyon şikâyeti olan toplam 50 hastadaki 100 eklemin sert dokularından kondile ait kemik değişiklikleri dental volumetrik tomografi ile incelendi.

DVT ile yapılan radyolojik incelemede, kondile ait kemik değişikliğinin dağılımı Tablo 1'de gösterildi.

Toplam 100 eklemin CBCT görüntülerinde 62 kondilde herhangi bir kemik değişikliği mevcut değilken; 38 kondilde kemik değişikliği tespit edilmiştir. Bu değişikliğin türü 14 kondilde düzleşme, 19 kondilde osteofit ve 5 kondilde ise erozyon formasyonu şeklindeydi (Tablo 1).

Tablo 1. Kondile ait kemik değişikliğinin dağıımı.

\begin{tabular}{|l|l|}
\hline KONDİLE AİT KEMİK DEĞİŞİKLİKLERİ & $\mathbf{n ~ ( \% )}$ \\
\hline Normal & $62(62.0)$ \\
\hline Düzleşme & $14(14.0)$ \\
\hline Osteofit & $19(19.0)$ \\
\hline Erozyon & $5(5.0)$ \\
\hline Toplam & $100(100.0)$ \\
\hline
\end{tabular}

DVT ile yapılan radyolojik incelemede kondiler kemik değişikliği ile yaş grupları arasında ilişki tespit edilen olguların sayısı ve istatistiksel karşılaştırması Tablo 2'de gösterildi.

Kondile ait kemik değişikliklerinin varlığı ile hastaların yaş aralıkları karşılaştırıldığında, çalışmaya dâhil edilen 18-39 yaş aralığındaki 64 kondilin 21 (\% 32.8)'inde ve 40-60 yaş arası 36 kondilin 17 (\% 47.2)'sinde kondile ait kemik değişikliklerin mevcut olduğu saptanmıştır. Bu bulguların altında kondiler kemik değişikliğinin varlığı ile yaş arasındaki ilişki istatistiksel olarak önemsizdir ( $p>0.05$ ) (Tablo 2).

Tablo 2. Kondiler kemik değişikliği ile yaş grupları arasındaki ilişki.

\begin{tabular}{|c|c|c|c|c|c|c|c|c|}
\hline & \multicolumn{6}{|c|}{ KONDİLER KEMİK DEĞİŞİKLİĞİ } & \multirow{3}{*}{ P değeri } \\
\hline & & \multicolumn{2}{|c|}{ Var } & \multicolumn{2}{|c|}{ Yok } & \multicolumn{2}{|c|}{ Toplamam } & \\
\hline & & $\mathrm{n}$ & $\%$ & $\mathrm{n}$ & $\%$ & $\mathrm{n}$ & $\%$ & \\
\hline \multirow{2}{*}{ YAŞ GRUPLARI } & $18-39$ & 21 & 32.8 & 43 & 67.2 & 64 & 100 & \multirow[t]{2}{*}{, 372* } \\
\hline & $40-60$ & 17 & 47.2 & 19 & 52.8 & 36 & 100 & \\
\hline
\end{tabular}


DVT görüntüleme yöntemindeki TME kondil dejenerasyonu saptanan ve saptanmayan bireylerin cinsiyet dağılımında; kondile ait kemik değişikliğinin mevcut olmadığı 62 eklemin 31'nin bayan ve 31'nin de erkek bireylere ait oldugu gözlemlendi. Kondiler kemik değişikliğinin tespit edildiği 38 eklemin 19'unun bayan bireylere 19'nun da erkek bireylere ait olduğu belirlendi. Bu bulguların ışığı altında kondiler kemik değişikliğinin varlığı ile cinsiyet arasındaki ilişki istatistiksel olarak önemsizdir ( $p>0.05$ ) (Tablo 3).

Tablo 3. Kondiler kemik değişikliği ile cinsiyet grupları arasındaki ilişki.

\begin{tabular}{|c|c|c|c|c|c|c|c|c|}
\hline & \multicolumn{6}{|c|}{ KONDİLER KEMİK DEĞİșİKLİĞİ } & \multirow[t]{3}{*}{$\mathrm{P}$ değeri } \\
\hline & & \multicolumn{2}{|r|}{ Var } & \multicolumn{2}{|r|}{ Yok } & \multicolumn{2}{|c|}{ Toplam } & \\
\hline & & $\mathrm{n}$ & $\%$ & $\mathrm{n}$ & $\%$ & $\mathrm{n}$ & $\%$ & \\
\hline \multirow[t]{2}{*}{ CINSIIYET } & Kadın & 19 & 38,00 & 31 & 62,00 & 50 & 100 & ,582** \\
\hline & Erkek & 19 & 38,00 & 31 & 6200 & 50 & 100 & \\
\hline
\end{tabular}

Kondiler kemik değişikliği ile ağrı semptomları arasındaki ilişkide; ağrının eşlik ettiği 76 eklemden 35 (\%46.1)'inde eklemde kondiler kemik değişikliği mevcutken 41 (\%53.9) kondilde herhangi bir değişiklik gözlemlenmedi. Ağrının olmadığı 24 vakada ise 3 (\% 12.5) kondilde kemik değişikliği mevcutken 21 (87.5) kondil normal morfolojide izlendi. Bu veriler altında kondiler kemik değişikliği ile ağrı arasındaki ilişki istatistiksel önemlidir $(p<0.05)$ (Tablo 4).

Tablo 4. Kondiler kemik değişikliği ile ağrı grupları arasındaki ilişki.

\begin{tabular}{|c|c|c|c|c|c|c|c|c|}
\hline & \multicolumn{6}{|c|}{ KONDİLER KEMİK DEĞİŞ̦̇́KLİĞİ } & \multirow[t]{3}{*}{ P değeri } \\
\hline & & \multicolumn{2}{|c|}{ Var } & \multicolumn{2}{|c|}{ Yok } & \multicolumn{2}{|c|}{ Toplam } & \\
\hline & & $\mathrm{n}$ & $\%$ & $\mathrm{n}$ & $\%$ & $\mathrm{n}$ & $\%$ & \\
\hline \multirow[t]{2}{*}{ AĞRI } & Var & 35 & 46,10 & 41 & 53,90 & 76 & 100 &, $002 * *$ \\
\hline & Yok & 3 & 12,50 & 21 & 87,5 & 24 & 100 & \\
\hline
\end{tabular}

Kondiler kemik değişikliği ile eklem sesleri arasındaki ilişkide; sesin eşlik ettiği 74 eklemin 32'sinde kondile ait kemik değişikliği mevcutken 42 kondilde herhangi bir değişiklik gözlemlenmedi. Sesin olmadığı 26 eklemde ise 6 kondilde kemik değişikliği mevcutken 20 kondil normal olarak izlendi. Bu verilerin altında kondiler kemik değişikliği ile ses arasındaki ilişki istatistiksel olarak önemsizdir ( $p>0.05$ ) (Tablo 5).

Tablo 5. Kondiler kemik değişikliği ile ses arasındaki ilişki.

\begin{tabular}{|c|c|c|c|c|c|c|c|}
\hline & \multicolumn{6}{|c|}{ KONDİLER KEMİK DEĞİŞİKLİĞİ } & \multirow{3}{*}{$P$ değeri } \\
\hline & \multicolumn{2}{|c|}{ Var } & \multicolumn{2}{|c|}{ Yok } & \multicolumn{2}{|c|}{ Toplam } & \\
\hline & $\mathrm{n}$ & $\%$ & $\mathrm{n}$ & $\%$ & $\mathrm{n}$ & $\%$ & \\
\hline SES $\mid$ Var & 32 & 43,25 & 42 & 56,75 & 74 & 100 &, $064 * *$ \\
\hline Yok & 6 & 23,10 & 20 & 76,90 & 26 & 100 & \\
\hline
\end{tabular}

TME 'deki hareket değişikliği ile kondiler kemik değişikliği arasındaki ilişkiye bağlı olarak yapılan CBCT değerlendirmesine göre hareket değişikliği mevcut olan 67 eklemden 31'inde kondiler kemik değişikliğinin olduğu, 36 eklemde ise hareket değişikliği olmasına rağmen kondiler kemik değişikliğinin olmadığı izlendi. Ayrıca hareket değişikliğinin olmadığı 33 eklemden 7'sinde kondiler kemik değişikliği izlenirken 26 eklemde kemik değişikliği görülmedi. Bu bulguların ışı̆ı altında hareket değişikliği ile kondiler kemik değişikliğinin varlığı arasındaki ilişki istatististiksel olarak önemsizdir ( $p>0.05$ ) (Tablo 6).

Tablo 6. Kondiler kemik değişikliği ile hareket değişikliği arasındaki ilişki.

\begin{tabular}{|c|c|c|c|c|c|c|c|c|}
\hline & \multicolumn{6}{|c|}{ KONDİLER KEMİK DEĞİŞİKLİĞİ } & \multirow{3}{*}{ P değeri } \\
\hline & & \multicolumn{2}{|l|}{ Var } & \multicolumn{2}{|c|}{ Yok } & \multicolumn{2}{|c|}{ Toplam } & \\
\hline & & $\mathrm{n}$ & $\%$ & $\mathrm{n}$ & $\%$ & $\mathrm{n}$ & $\%$ & \\
\hline \multirow{2}{*}{\begin{tabular}{|l|} 
HAREKET \\
DEĞİşİKLİĞİ
\end{tabular}} & Var & 31 & 46,26 & 36 & 53,74 & 67 & 100 & \multirow[t]{2}{*}{, $072 * *$} \\
\hline & Yok & 7 & 21,21 & 26 & 78,79 & 33 & 100 & \\
\hline
\end{tabular}

Kondiler kemik değişikliği ile zararlı alışkanlıklar arasındaki ilişkide; zararlı alışkanlıkları bulunan hastalara ait 29 eklemin 15'inde eklemde kondiler kemik değişikliği mevcutken, 14 kondilde morfolojik olarak herhangi bir değişiklik gözlemlenmedi. Zararlı alışkanIıkları olmayan hastalara ait 71 eklemin 23'ünde, kondilde kemik değişikliği mevcutken 48 kondil normal olarak izlendi. Bu verilerin ışığı altında kondiler kemik değişikliği ile zararlı alışkanlıkların varlığı arasındaki ilişki istatistiksel olarak önemlidir $(p<0.05)$ (Tablo 7).

Tablo 7. Kondiler kemik değişikliği ile zararlı alışkanlıklar arasındaki ilişki.

\begin{tabular}{|c|c|c|c|c|c|c|c|c|}
\hline & \multicolumn{6}{|c|}{ KONDİLER KEMİK DEĞİŞİKLİĞİ } & \multirow[t]{3}{*}{ P değeri } \\
\hline & & \multicolumn{2}{|c|}{ Var } & \multicolumn{2}{|c|}{ Yok } & \multicolumn{2}{|c|}{ Toplam } & \\
\hline & & $\mathrm{n}$ & $\%$ & $n$ & $\%$ & $\mathrm{n}$ & $\%$ & \\
\hline \multirow{2}{*}{\begin{tabular}{|c|} 
ZARARLI \\
ALISSKANLIKLAR
\end{tabular}} & Var & 15 & 51,72 & 14 & 48,28 & 29 & 100 & \multirow[t]{2}{*}{,048* } \\
\hline & Yok & 23 & 32,40 & 48 & 69,60 & 71 & 100 & \\
\hline
\end{tabular}

Hastalarımıza ait kondiler kemik değişiklikleri ve kondiler hareket değişiklikleri aşağıda gösterilmiştir (Şekil 1,2).

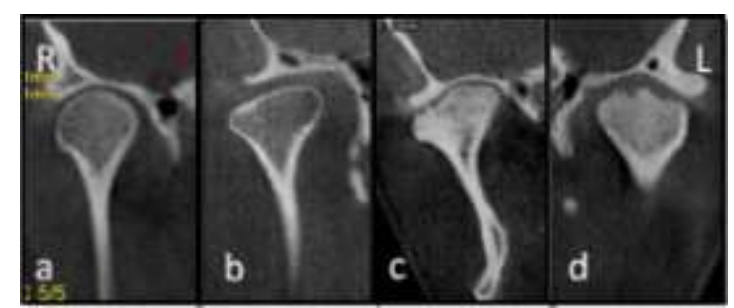

Şekil 1. Kondiler kemik değişiklikleri: a) Normal kondil (yuvarlak tip), b) düzleşme c) osteofit d) erozyon 


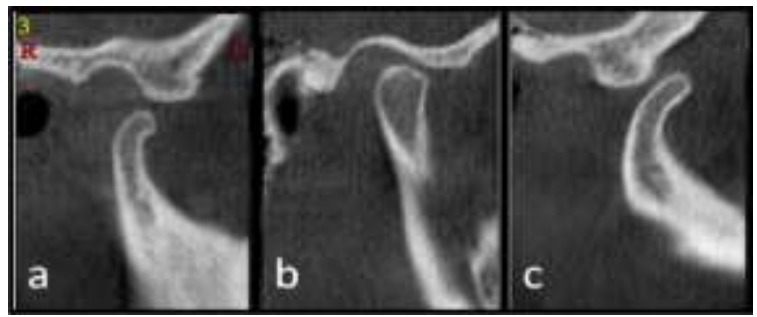

Şekil 2. Kondiler hareket değişiklikleri: a) Normal kondil hareketi (eminens normal), b) hipomobil kondil (eminenste düzleşme) c) sublüksasyon

\section{TARTIŞMA}

TME disfonksiyonları çenelerde ağrı ve hassasiyetin dışında baş ve boyun ağrısı gibi farklı sıkıntılara neden olabilirler. Bu semptomların tümü internal düzensizlik (kondil-disk uyumsuzluğu), osteoartroz ve travma gibi mandibular kondil disfonksiyonları ile ilişkili olabilir. $^{3}$

Vücuttaki tüm eklemlerde olduğu gibi temporomandibular eklemde de sürekli bir remodeling varlığı söz konusudur. Remodelingde temel fonksiyon eklemin artiküler yüzeyleri arasındaki mekanik ve fonksiyonel ilişkiyi devam ettirmektir. Remodeling; eklem formunun korunmasına ve normal fonksiyonel gereksinimlerine verilen esansiyel bir biyolojik cevaptır. TME'de iki tür remodeling aktivitesinin gerçekleştiği düşünülmektedir. Fonksiyonel remodeling oklüzyon veya eklemin mekanik fonksiyonlarında herhangi bir anlamlı değişiklik ile ilişkisi olmayan remodelingdir. Disfonksiyonel remodeling ise oklüzyon ve eklemin mekanik fonksiyonlarını kötü şekilde etkileyen remodelingdir. Fonksiyonel ve disfonksiyonel remodeling benzer şekildeki mekanizmaların ürünü değildir. Disfonksiyonel remodeling geniş kapsamlıdır ve dejeneratif eklem hastalığı, osteoartroz ve osteoartrit gibi geleneksel hastalık türlerini ihtiva etmektedir. ${ }^{4}$

Mandibular kondil de hem fonksiyonel hem de disfonksiyonel remodelingden hayat boyunca etkilenir. ${ }^{5}$ Literatürde, oluşan bu kemik değişikliklerine ait farklı sınıflamalar vardır.,6-8 $\mathrm{Bu}$ sınıflamalara bakıldığında; Oberg ve arkadaşları $^{6}$ artiküler yüzeylerde erozyon ya da pürüzlerin varlığını osteoartrotik, remodeling ya da değişiklik göstermeyen artiküler yüzeyleri ise nonartrotik olarak sınıflandırmışlardır. Nanthaviroj ve arkadaşları ${ }^{9}$ kemik değişikliklerini erozyonlar, düzleşmeler, osteofitler, sklerozis ve subkondral kistler seklinde sınıflandırmışlardır. Koyama ve arkadaşları ${ }^{10}$ helikal BT'de kemik değişikliğinin olmadığı vakaları N, düzleşmenin olduğu vakaları $F$, pürüzlü ya da pürüzsüz erozyonun olduğu vakaları $E$, deformiteleri $D$ ve pürüzlü ya da pürüzsüz erozyonun eşlik ettiği deformiteleri ise $\mathrm{S}$ olmak üzere beş sınıfa ayırmışlardır. Wiberg ve Wanman ${ }^{11}$ kemik değişikliklerini normal kemik, düzleşme-osteofit- subkondral sklerozisi içeren değişiklikleri morfolojik kemik ve kondil veya temporal kemiğin kortikal yüzeylerinin yıkım ya da bütünlüğünün bozulmasını da eroziv kemik değişikliği olarak sınıflandırmıştır. Yamada ve arkadaşları ${ }^{12}$ kondiler kemik değişikliklerini normal, düzleşme, osteofit ve erozyon şeklinde sınıflandırdı. Çalışmamızda, bahsedilen sınıflamalar arasında radyografinin tek başına yeterli olduğu, histolojik inceleme gerektirmeyen, literatürde kullanım kolaylığı sağlayan ve genellikle tercih edilen Yamada ve arkadaşlarının ${ }^{12}$ sınıflamasını kullanılmıştır.

TME'deki kemik komponentlerine ait disfonksiyonel remodelingden kaynaklı bu değişikliklerin belirlenmesinde bilgisayarlı tomografinin diğer imaj tekniklerine göre üstünlüğü birçok çalışma ile desteklenmiştir. Honda ve arkadaşları ${ }^{13}$ (2006), kondillerdeki kemik değişikliklerinin incelenmesi konusunda helikal BT ile CBCT'yi karşılaştırmışlardır. Araştırmacılar hem helikal BT hem de CBCT'nin, mandibula kondilinin değerlendirilmesinde yüksek güvenilirliğe sahip olduklarını ortaya koymuşlardır. Hintze ve arkadaşları ${ }^{14}$ kondil ve artiküler tüberkül açısından morfolojik değişikliklerin tespitinde BT'nin, tek başına lateral imajların alındığı CBCT'ye kıyasla daha yüksek doğruluk gösterdiğini ifade etmişlerdir. Ancak tek başına frontal ya da fronto-lateral imajların kombine olduğu $\mathrm{CBCT}$ ve BT'nin, eminens ve kondile ait morfolojik değişikliklerin tepsitinde herhangi bir farklılık arz etmediğini belirtmişlerdir.

Tsiklakis ve arkadaşlarl ${ }^{15}$ TME'nin görüntülenmesi üzerine yaptıkları teknik bir çalışmada, yeni bir yöntem olan CBCT ile TME'nin kemik komponenetlerinin radyografik açıdan tam olarak incelenebileceğini bildirmişlerdir. Bu çalışmada ayrıca, CBCT'nin inceleme zamanının kısa, radyasyon dozunun kon- vansiyonel tomografilere göre oldukça düşük ve rekonstrüksiyon imajlarının diagnostik kalitesinin de yeterince yüksek olduğunu bildirmişlerdir. Marques ve arkadaşlarının ${ }^{16}$ yaptıkları bir çalışmada, kondil başı ve onu ilgilendiren kemik lezyonlarını değerlendirmede CBCT'nin etkinliğinin yeterli olduğu bulunmuştur. Meng ve arkadaşları ${ }^{17}$ yaptıkları bir çalışmada CBCT ile TME'in kemik komponentlerinin tam olarak incelene- bileceğini ve TME osteoartitlerini değerlendirmede en etkili yöntemlerden biri olduğunu bildirmişlerdir.

Geleneksel BT cihazlarında temporomandibular ekleme ait direkt koronal görüntülerin oluşturulması, 
boyun omurlarını etkileyen dejeneratif kemik hastalığı olan bireyler ve yaşlılarda boynun aşırı geriye yatırılmasını gerektirir ve bu durum oldukça rahatsız edicidir. ${ }^{18}$ Uzun tarama zamanı bu rahatsız pozisyonlandırılma ile birleştirilince sıklıkla hareket artefaktlarıyla sonuçlanmaktadır. Oysaki, DVT koronal rekonstrüksiyon imajlarında pozisyonlandırma zorluğu yoktur. Geleneksel koronal BT'deki imajlarda, dental amalgamlardan kaynaklanan artefaklar oluşur. ${ }^{19,20}$ Çok sayıda amalgam restorasyon varlığında supin pozisyonu ile alınan koronal rekonstrüksiyonlar artefaktları azaltmak için tercih edilebilir. ${ }^{21}$ Çalışmamızda supin pozisyonda ve aksiyal planda yapılan TME-DVT incelemesi ile elde edilen sagittal ve koronal rekonstrüksiyonlar üzerinde TME değerlendirmesi yapılmıştır.

Çalışmamızda Dental Volumetrik Tomografi ile TME disfonksiyon şikâyeti olan toplam 50 hastanın mandibular kondillerindeki kemik değişiklikleri incelenmiştir. Bu amaçla birtakım epidemiyolojik metotlar kullanılmıştır. Ancak bazı araştırmacılar bu yöntemlerin kullanılmasında problemler oluşabileceğini belirtmişlerdir. $^{22,23} \mathrm{Bu}$ yüzden araştırmamızda TME disfonksiyonlarının subjektif ve objektif incelenmesi amacıyla araştırmacıların genellikle fikir birliği yaptığı semptomlar (mandibular hareketlerde kısıtlanma, çiğneme kaslarında ağrı, TME ağrısı, eklem sesleri, çene hareketlerindeki değişiklikler) incelenmiştir. ${ }^{24}$

Widmalm ve arkadaşları $^{25}$ (1994) otopsi materyali üzerinde TME'ye ait morfolojik değişiklikleri inceledikleri çalışmasında 80 yaşın altındaki kadın ve erkeklerde bu değişikliklerin benzer seyrettiğini tespit etmişlerdir. Kurita ve arkadaşları ${ }^{26}$ (2004) yaptıkları bir çalışmada, cinsiyet ve diş kayıplarının kadavralarda TME'deki morfolojik değişikliklerin miktarı üzerinde bir etkisi olmadığı belirtmişlerdir. Çalışmamızdan elde ettiğimiz sonuçlara göre, kondiler kemik değişikliği ile cinsiyet arasında istatistiksel olarak herhangi bir ilişki bulunmadığından bulgularımız her iki çalışmayı da desteklemektedir. Mevcut sonuçlar TME ağrı ve disfonksiyonu nedeniyle tedavi arayışı içinde olan hastalarda kadın/erkek oranının baskın şekilde kadınlardan yana olduğu klinik bulgusu ile uyuşmamaktadır.

TME osteoartrozunun rapor edilmiş prevalansı 20-90 yaş arasındaki popülasyonda \% 22 ile \% 38 arasında sıralanmaktadır ve TME osteoartroz prevalansı yaş ile artar. ${ }^{11}$ Otopsi çalışmalarına göre osteoartroz semptomlarının 60 ile 80 yaş arasındaki insanlarda \% 80 gibi büyük oranda bulunduğu gösterilmiştir ancak böyle semptomlar 40 yaşının altındaki insanlarda nadir bulunmuştur. ${ }^{11,27,28} 40$ yaşın altındaki ve üs- tündeki kişilerde TME'nin kemik komponentlerinin farklı sahalarındaki dejeneratif osteoartritik değişikliklerinin oluşumunun incelendiği son bir otopsi çalışmasında OA septomları 40 yaşının altındakilerin \% 4'ünde; 40 yaşının üstündeki kişilerin ise \% 22'sinde belirlenmiştir. ${ }^{25}$ Genç insanlardaki bu sonuçlar Dibbet ve Carlson'in ${ }^{29}$ ortaya koyduğu bulgular ile uyuşmamaktadır. Dibbet ve Carlson ${ }^{29}$ ortodontik tedavi için başvuran çocukların ilk muayenesinde \% 16'sında, 2 yıllık takip sonundaki incelemelerinde ise \% 24'ünde kondildeki değişikliklerin varlığını rapor etmişlerdir. Huja ve arkadaşları ${ }^{30}$ yaptığı hayvan çalışmasında, genç ve yetişkin köpeklerin kondil kemiğindeki sertlik ve çentikleşme durumunu incelemişlerdir. Yetişkin köpeklerin kondilindeki çentikleşmeyi genç köpeklere nazaran anlamlı şekilde daha yüksek bulmuşlardır. Tüm bunlar yaş ile köpeklerdeki mandibular kondilin trabeküler kemiğindeki materyal özelliklerinin değiştiğini göstermektedir. Koyama ve arkadaşları ${ }^{10}$ TMED'ye sahip 516 hastadaki 1032 ekleme ait kondiler kemik değişikliklerinin prevalansını ve bu kemik değişikliklerinin farklı kemik değişikliklerine dönüşümünü 3 ile 18 ay arasındaki takip dönemlerinde incelemişler ve 1032 eklemin 617'sinde kondiler kemik değişikliği tespit etmişledir. Ayrıca 102 eklemin 70'inde de eklem kondilinde zamanla kemik değişikliğinin tipinde değişiklikler belirlemişlerdir. Bu sonuçlar TMED'li kişilerde kondiler kemik değişikliğindeki farklılaşmanın ana yönünün sklerotik kemik değişikliklerine doğru olduğunu göstermiştir. Mevcut incelememizde yaşla birlikte morfolojik değişikliklerin sıklığında bir artış tespit edilmiştir. Bununla birlikte yaşlı hastalarda semptomların daha düşük sıklıkta oluştuğunu biliyoruz. Başka bir deyişle yaşla artan morfolojik değişikliklerin aksine yaşı kişiler arasında tedavi intiyaç talebi nispeten daha düşük bulunmuştur. Bunun nedeni eklemdeki morfolojik değişiklerin büyük oranda klinik semptomlarla ilişkili olmamasıdır. Hasta teşhisi ve tedavi planlaması eklemdeki morfolojik değişikliklerin varlığından ziyade klinik inceleme bulgularının temeline dayanmaktadır.

Diş sıkma ve diş gıcırdatma gibi parafonksiyonel alışkanlıkların bireyin fizyolojik toleransını aştığı durumlarda TME sistemi içerisinde değişikliklere ve bozulmalara neden olduğu rapor edilmiştir. Bu alışkanlıklar mekanik streslerin sebebi olarak kabul edilir. Uy-Co ve arkadaşları ${ }^{31}$ (2000) kondile ait kemik değişikliklerinin çene deformitesine sahip kişilerde kraniofasial deformite ile ilişkili olduğunu ve bu deformitelerin sebebinin kondile ait kemik değişikliklerine sebep olan mekanik stres faktörlerinden parafonk- 
siyenel alışkanlıklar altında araştırıması gerektiğini vurgulamışlardır. Yamada ve arkadaşları ${ }^{32}$ (2001) diş sıkma ve diş gıcırdatma alışkanlığı ile kondile ait kemik değişiklikleri arasında ilişki olduğunu ve 3 veya daha fazla parafonksiyonel aktiviteye sahip bireylerin yüksek oranda bilateral kondile ait kemik değişikliklerini sergilediğini tespit etmişledir. Bizim bulgularımı bu durumu desteklemektedir. Sonuçlarımıza göre diş sıkma ve gıcırdatma gibi fonksiyon dışı mastikatör kas aktiviteleri ile eklem üzerinde oluşan aşırı yüklenme TME'deki kemik değişikliklerinin etiyolojisine katkıda bulunmaktadır. Stegenga ve arkadaşları ${ }^{5}$ (1989) ile Bont ve Stegenga ${ }^{33}$ (1993) TME dokuları üzerinde fonksiyonel adaptif kapasite aşımının sinoviyal SIVı değişiklikleri ile kondrosit beslenmesi ve lubrikasyonu üzerinde bozulmalara ve kıkırdak yapım ve yıkım arasındaki denge değişimi ile morfolojik değişikliklerin oluştuğuna vurgu yapmaktadırlar. Birçok araştırmacı TME'ye ait internal düzensizlikler ile kondile ait kemik değişiklikleri arasındaki mevcut ilişkiden bahsetmişler, internal düzensizliğe sahip eklemlerdeki anormal kuvvetlerin dejeneratif değişiklikler ve sekonder remodeling aktiviteleri ile ilişkili olabileceğini vurgulamışlardır. Çalışmamızda kondiler kemik değişikliği ile eklem palpasyonu veya mandibular fonksiyonda ortaya çıkan ve internal düzensizliklerin temel semptomlarından biri olan ağrı arasındaki ilişki istatistiksel olarak önemli bulunmuştur. Bu bulgu Kurita ve arkadaşlarını ${ }^{26}$ destekliyor. Bizim bulgularımıza benzer şekilde Bertram ve arkadaşları, ${ }^{34}$ Emshoff ve arkadaşlar ${ }^{35}$ ile Nebbe ve

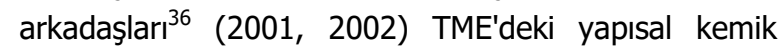
değişiklikleri ile eklemle ilişkili ağrı arasında önemli bir ilişkiyi rapor etmişlerdir. Mevcut durumlarda ortaya çıkan bu ağrı, fonksiyon esnasında aşııı yüke maruz kalan kondilin artiküler yüzeyinde oluşan dejeneratif değişimlerle ilgili olabilir. Başka bir deyişle mandibular hareket esnasında artmış olan yük, mandibular fonksiyondaki eklem ağrısının ana faktörü olabilir. Bu fikir, eklem yükünü hafifletmek için uygulanan tedavi stratejilerinin etkinliğini de destekleyebilir. Bununla birlikte asemptomatik çene eklemlerinde kemik değişikliklerinin yüksek prevalanstaki radyografik işaretleri rapor edilmiş ve mandibular fonksiyon esnasında eklemde ortaya çıkan ağrının osteoartroz için güvenli bir işaret olmadığı önerilmiştir. Eklemin değişik komponentlerindeki ve periartiküler dokulardaki mekanik (artmış basınç ve destrüksiyon) ve kimyasal (enflamatuar kaynaklar) stimülanlar eklem ağrısının olası sebepleridir. Manyetik rezonans imajlarda bir eklem efüzyonu olarak yorumlanan yüksek sinyal intesiteleri eklem ağrısı ile ilişkili olarak düşünülmüş ve ağrının sebebi osteoartrozdan ziyade kapsüler dokuların synoviti veya enflamasyonu gibi durumlar olarak düşünülmüştür. Bu mevcut iki görüşten dolayı eklem kaynaklı ağrıya sahip disfonksiyonlu bireylerin eklem osteoartrozunun spesifik işaretlerinin varlı̆ı açısından kontrol gurubu bireylerden farklılaşıp farklılaşmadığını test etmek için ileri incelemelerin varlığına intiyaç vardır.

Mevcut literatürde temporomandibular eklem dejenerasyonu ile fasial deformite arasındaki ilişki araştıııılar tarafından rapor edilmiş ve kondile ait kemik değişikliği ve disk deplasmanı gibi ekleme ait bozulmaların özellikle çocukluk çağında mandibular büyümede azalmaya ve bunun sonucunda mandibular retrüzyon ve deviasyona neden olabileceği önerilmiştir. Yamada ve arkadaşları, ${ }^{12}$ Nebbe ve arkadaşları, ${ }^{36}$ Kerstens ve arkadaşları ${ }^{37}$ ile White ve Dolwick ${ }^{38}$ mandibular retrüzyonlu, mandibular deviasyonlu ve open biteli hastalarda klik ve krepitasyon gibi eklem seslerinin yüksek oranlarını ifade ettiler. İncelemelerimizde bu çalışmalarla uyumlu olarak istatistiksel olarak önemli olmasa da kemik değişikliği olan bireylerde olmayanlara kıyasla daha yüksek oranda eklem seslerinin varlığı tespit edilmiştir. Bu bulgular deplase disk ve kondiler kemik değişikliği ile ilişkili olabilen mandibular deviasyon ve retrüzyon gibi çene deformitelerinin varlığını gösteren manyetik rezonans ${ }^{37}$ ve bilgisayarlı tomografi raporlar1 ${ }^{12}$ ile uyumludur.

Mevcut incelemelerimizde kondile ait kemik değişikliklerinden düzleşme \% 14 olarak tespit edilmiştir. Brooks ve arkadaşları ${ }^{39}$ internal düzensizliği olmayan asemptomatik bireylerde kondil ve/veya artiküler eminense ait düzleşme sıklığını \%35 olarak tespit etmişler ve bu düzleşmelerin muhtemelen klinik önemden uzak tutulabileceğini ve internal düzensizliği olmayan asemptomatik kişilerde normal sınırlar içinde kabul edilebileceğini önermişlerdir. Bu nedenle düzleşmelerin kemik değişikliği olarak kabul edildiği veya edilmediği çalışmalar arasında ortaya çıkacak farklıık kaçınımazdır. Hasta seçim kriterleri, kullanılan radyografi teknikleri ve radyogramların yorumlanmasında ortaya çıkan farkılıkların da bu duruma katkı yapabileceği unutulmamalıdır.

\section{SONUÇ VE ÖNERİLER}

1. Dental volümetrik tomografi; TME'nin sert dokularına ait değişikliklerin en ince detayına kadar gözlemlenebilmesine imkân tanıdığı için TME hastalıklarının teşhisinde ve takibinde önemli bir basamak olarak yerini almalıdır. 
2. Tempromandibular eklem rahatsızlığı olan bireylerde mandibular kondil disfonksiyon aktivitesinden belirgin şekilde etkilenir. Bizim bulgularımıza göre bu durum etiyoloji açısından yaş ve cinsiyet guruplarında istatistiksel farklılık göstermezken; parafonksiyonel aktiviteye sahip bireylerde önemli şekilde yüksek bulunmuştur. Bu durum muhtemelen eklemde oluşan aşırı yüklenmeye bağlı olarak kemiğin verdiği cevaptır.

3. Oluşan bu kemik değişiklikleri ağrı ile ilişkiliyken ses ve hareket değişikliği guruplarında farklılık göstermemiştir. Bu noktadan hareketle hastaya bize getiren temel bulgunun osteoartroz işaretlerinden ziyade ağıı olduğu veya osteoartoz bulgularının klinik semptomlar ile uyuşmadığı sonucuna varabiliriz.

4. Eklem osteoartrozunun spesifik bulgularının varlığı açısından klinik semptomlara sahip disfonksiyonlu bireylerin kontrol gurubu bireylerden farklılaşıp farklılaşmadığını tespit etmek için ilave çalışmalara ihtiyaç duyulmaktadır.

NOT: Çalışmada herhangi bir yazar, kurum ya da kuruluş ile çıkar çatışması içerisinde bulunmamaktadır. Makale daha önce hiçbir yerde yayınlanmamış ve yayınlanmak üzere işlem görmemektedir

\section{KAYNAKLAR}

1. Okeson JP. Management of Temporomandibular Disorders and Occlusion. 5th ed. Mosby, 2003.

2. Yengin E. Temporomandibular Rahatsızlıklarda Teşhis ve Tedavi. Dilek Ofset Matbaacılık, 1. Baskı, İstanbul, 2000.

3. Wang $L$, Detamore MS. Tissue engineering the mandibular condyle. Tissue Eng 2007;13:1955-71.

4. Arnett GW, Milam SB, Gottesman L. Progressive mandibular retrusion-idiopathic condylar resorption. Part I. Am J Orthod Dentofacial Orthop 1996; 110:8-15.

5. Stegenga B, Bont LG, Boering G. Osteoartrosis as the cause of craniomandibular pain dysfunction: a unifying concept. J Oral Maxillofacial Surg 1989; 47: 249-56.

6. Oberg T, Carlsson GE, Fajers CM. The temporomandibular joint. A morphologic study on a human autopsy material. Acta Odontol Scand 1971; 29:349-84.

7. Westesson $\mathrm{PL}$, Katzberg RW, Tallents $\mathrm{RH}$, Sanchez-Woodworth RE, Svensson SA. CT and MR of the temporomandibular joint: comparison with autopsy specimens. AJR Am J Roentgenol 1987; 148:1165-71.

8. Tsuruta A, Yamada K, Hanada K, Koyama JI, Hayashi $T$, Hosogai $A$, et al. Comparison of condylar positions at intercuspal and reference positions in patients with condylar bone change. J Oral Rehabil 2004;31:640-6.

9. Nanthaviroj S, Omnell KA, Randow K, Oberg T. Clicking and temporary "locking" in the temporomandibular joint. A clinical, radiographical and electromyographical study. Dentomaxillofac Radiol 1976;5:33-8.

10. Koyama J, Nishiyama H, Hayashi T. Follow-up study of condylar bony changes using helical computed tomography in patients with temporomandibular disorder. Dentomaxillofac Radiol 2007;36:472-77.

11. Wiberg B, Wanman A. Signs of osteoarthrosis of the temporomandibular joints in young patients: $a$ clinical and radiographic study. Oral Surg Oral Med Oral Pathol Oral Radiol Endod 1998;86(2):158-64.

12. Yamada K, Hiruma Y, Hanada K, Hayashi T, Koyama J, Ito J. Condylar Bony Change and Craniofacial Morphology in Orthodontic Patients With Temporomandibular Disorders (TMD) Symptoms: A Pilot Study Using Helical Computed Tomography and Magnetic Resonance Imaging. Clin Orthod Res 1999;2:133-42.

13. Honda K, Larheim TA, Maruhashi K, Matsumoto K, Iwai $\mathrm{K}$. Osseous abnormalities of the mandibular condyle: diagnostic reliability of cone beam computed tomography compared with helical computed tomography based on an autopsy material. Dentomaxillofac Radiol 2006;35:152-7.

14. Hintze $H$, Wiese $M$, Wenzel $A$. Cone beam $C T$ and conventional tomography for the detection of morphological temporomandibular joint changes. Dentomaxillofac Radiol 2007;36:192-7.

15. Tsiklakis K, Syriopoulos K, Stamatakis HC. Radiographic examination of the temporomandibular joint using cone beam computed tomography. Dentomaxillofac Radiol 2004;33:196-201.

16. Marques AP, Perrella A, Arita ES, Pereira MF, Cavalcanti Mde G. Assessment of simulated mandibular condyle bone lesions by cone beam computed tomography. Braz Oral Res; 24:467-74.

17. Meng JH, Zhang WL, Liu DG, Zhao YP, Ma XC. Diagnostic evaluation of the temporomandibular joint osteoarthritis using cone beam computed tomography compared with conventional 
radiographic technology. Beijing Da Xue Xue Bao 2007;39:26-9.

18. Aygun N, Zinreich SJ. Imaging for functional endoscopic sinus surgery. Otolaryngol Clin North Am 2006;39:403-16.

19. Branstetter BFt, Weissman JL. Role of MR and CT in the paranasal sinuses. Otolaryngol Clin North Am 2005;38:1279-99.

20. Klevansky A. The efficacy of multiplanar reconstructions of helical CT of the paranasal sinuses. AJR Am J Roentgenol 1999;173:493-5.

21. Eggesbo HB. Radiological imaging of inflammatory lesions in the nasal cavity and paranasal sinuses. Eur Radiol 2006;16:872-88.

22. Greene CS, Marbach JJ. Epidemiologic studies of mandibular dysfunction: a critical review. J Prosthet Dent 1982;48:184-90.

23. van der Weele LT, Dibbets JM. Helkimo's index: a scale or just a set of symptoms? J Oral Rehabil 1987; 14:229-37.

24. Kaplan AS, Assael LA. Temporomandibular Disorders: Diagnosis and Treatment, Philadelphia, WB. Saunders Co., London, 1991:97-103.

25. Widmalm SE, Westesson PL, Kim IK, Pereira FJ, Jr., Lundh $\mathrm{H}$, Tasaki MM. Temporomandibular joint pathosis related to sex, age, and dentition in autopsy material. Oral Surg Oral Med Oral Pathol 1994;78:416-25.

26. Kurita H, Kojima Y, Nakatsuka A, Koike T, Kobayashi $\mathrm{H}$, Kurashina K. Relationship between temporomandibular joint (TMJ)-related pain and morphological changes of the TMJ condyle in patients with temporomandibular disorders. Dentomaxillofac Radiol 2004;33: 329-33.

27. Solberg WK, Hansson TL, Nordstrom B. The temporomandibular joint in young adults at autopsy: a morphologic classification and evaluation. J Oral Rehabil 1985;12:303-21.

28. Akerman S, Rohlin M, Kopp S. Bilateral degenerative changes and deviation in form of temporomandibular joints. An autopsy study of elderly individuals. Acta Odontol Scand 1984;42: 205-14.

29. Dibbets JM, Carlson DS. Implications of temporomandibular disorders for facial growth and orthodontic treatment. Semin Orthod 1995;1:258-72.

30. Huja SS, Rummel AM, Beck FM. Changes in mechanical properties of bone within the mandibular condyle with age. J Morphol 2008;269:138-43.

31. Uy-Co ET YK, hanada K, Hayashi T, Ito J. Condylar bone change and mandibular deviation in orthodontic patients: using helical CT and MRI. Clin Orth Res 2000; 3:132-43.

32. Yamada K, Hanada K, Fukui T, Satou Y, Ochi K, Hayashi $T$, et al. Condylar bony change and selfreported parafunctional habits in prospective orthognathic surgery patients with temporomandibular disorders. Oral Surg Oral Med Oral Pathol Oral Radiol Endod 2001;92:265-71.

33. de Bont LG, Stegenga B. Pathology of temporomandibular joint internal derangement and osteoarthrosis. Int J Oral Maxillofac Surg 1993; 22: 71-4.

34. Bertram S, Rudisch A, Innerhofer K, Pumpel E, Grubwieser G, Emshoff R. Diagnosing TMJ internal derangement and osteoarthritis with magnetic resonance imaging. $\mathrm{J} \mathrm{Am}$ Dent Assoc 2001;132:753-61.

35. Emshoff R IK, Rudisch A, Bertram S. The biological concept of "internal derangement and osteoarthrosis": a diagnostic approach in patients with temporomandibular joint pain? Oral Surg Oral Med Oral Pathol Oral Radiol Endod 2002;93:39-44.

36. Nebbe B, Major PW, Prasad NG, Grace M, Kamelchuk LS. TMJ internal derangement and adolescent craniofacial morphology: a pilot study. Angle Orthod 1997;67:407-14.

37. Kerstens HC, Tuinzing DB, van der Kwast W A. Temporomandibular joint symptoms in orthognathic surgery. J Craniomaxillofac Surg 1989;17:215-8.

38. White CS, Dolwick MF. Prevalence and variance of temporomandibular dysfunction in orthognathic surgery patients. Int J Adult Orthodon Orthognath Surg 1992;7:7-14.

39. Brooks SL, Westesson PL, Eriksson L, Hansson LG, Barsotti JB. Prevalence of osseous changes in the temporomandibular joint of asymptomatic persons without internal derangement. Oral Surg Oral Med Oral Pathol 1992; 73:118-22.

\section{Yazışma Adresi}

Dr. Öğr. Üyesi Doğan DURNA

Atatürk Üniv. Diş Hek Fak Ağız, Diş ve Çene

Radyolojisi AD, ERZURUM

E-posta: dogandurna@atauni.edu.tr 